\title{
CONSUMER SATISFACTION TOWARDS GREEN TEA IN COIMBATORE CITY
}

\author{
K. VISHNU PRASATH ${ }^{1} \&$ Dr. R. BALAJI ${ }^{2}$ \\ ${ }^{I}$ PG Scholar - MBA (Agribusiness Management), Dept. of ARM, Directorate of Agri Business Development, \\ Tamilnadu Agricultural University, Coimbatore, Tamilnadu, India \\ ${ }^{2}$ Assistant Professor (HRM), Directorate of Agri Business Development, Tamilnadu Agricultural University, \\ Coimbatore, Tamilnadu, India
}

The study deals with satisfaction level of green tea among urban people. The Coimbatore city was purposively selected and the exploratory research design was adopted for the research. Survey method was used in which general profile of the sample respondents were identified. In worldwide scenario, tea is considered as most widely consumed beverage and tea drinking is also associated with various health benefits. The medicinal properties have been scientifically investigated in recent years. In India, green tea consumption has increased due to consumer preference towards green tea. There are various types of tea such as white tea, black tea, green tea and oolong tea. Among the various types of tea, green tea is used as a substitute for regular tea. The various health benefits of green tea were mainly due to the presence of higher amount of antioxidants and it was called as polyphenols. The sample area in which Coimbatore district was selected purposively and totally 140 respondents were also selected purposively and the survey is done through interview schedule. It was concluded that the majority (85 percent) of the sample respondents are highly dissatisfied because of the taste of green tea and 92.85 percent of the sample respondents are highly dissatisfied because of the odourless nature of the green tea. Majority (93.57) percent of the sample respondents are highly satisfied as green tea contains antioxidants, vitamins and minerals. Also, 96.42 percent of the sample respondents are highly satisfied by drinking green tea as it improves their health. Majority (75.71 percent) of the sample respondents are highly satisfied by drinking green tea as it helps to lower cholesterol level. Majority (70.71 percent) of the sample respondents are highly satisfied as green tea is familiar with their family, 50 percent of the sample respondents are satisfied by the ecofriendly packaging of the green tea and nearly 25 percent of the sample respondents are highly satisfied with the ecofriendly packaging of green tea. Almost 96.42 percent of the sample respondents are highly satisfied with the origin of the production of green tea. Majority (60 percent) of the sample respondents are highly dissatisfied by the expensive price of green tea and 60 percent of the sample respondents are highly satisfied and 40 percent of the sample respondents are dissatisfied by the cost of green tea. Almost 100 percent of the sample respondents are highly satisfied as green tea is easy to prepare. Also, 100 percent of the sample respondents are highly satisfied as it takes no time to prepare and 42.14 percent of the sample respondents are highly satisfied as that green tea can be bought easily at nearby shops. Mostly 100 percent of the sample respondents are highly satisfied as green tea is easily available in shops and supermarkets. Almost 94.28 percent of the sample respondents are satisfied as purchasing green tea is a good value of money and price is considered as an important constraint by the green tea consumers because the price of green tea is high.

KEYWORDS: Green Tea, Consumption Pattern, Polyphenols and Antioxidants
\end{abstract}

Received: Feb 21, 2021; Accepted: Mar 11, 2021; Published: Mar 23, 2021; Paper Id.: IJESRAPR20214

\section{INTRODUCTION}

Across the world, green tea is considered as a popular beverage particularly in Asian countries such as Japan, Korea and China. In comparison with black tea, green tea contains more amounts of catechins and it is 
non-fermented. Over 80 percent of the worldwide consumers are black tea consumers, but in recent years, nearly 90 percent (Source-www.teaboard.gov.in) of the people consume green tea. Thus, the consumption of green tea has increased. Nowadays, green tea has been used as a substitute for regular tea and also it consists of various health benefits such as lowers blood sugar level, lowers cholesterol, it lowers the risk of cancer, obesity and diabetes, etc. Green tea is now becoming a popular drink across different age groups due to its perceived health benefits and is fast becoming one of the popular products in health and wellness segments.Green tea has now become popular and there are various brand players in green tea. The study was initiated with the following objectives.

\section{Objectives of the study}

- To analyse level of satisfaction towards green tea.

- To identify the constraints faced by the consumers and offer suitable strategies.

\section{MATERIALS AND METHODS}

Methodology includes devices, techniques and procedures for conducting research, the study in which concerned research methodology are as follows

\subsection{Scope of the Study}

The present study is used to analyze the satisfaction level of green tea consumers in Coimbatore city.

\subsection{Sampling Design}

Survey method was used in this study. In this study, purposive sampling technique is used to collect data from the respondents in Coimbatore city. 140 respondents were selected for the study. Purposive sampling technique is used because this study focuses on targeted consumers. Also, awareness and consumption of green tea is more in this city. Since there are more urbanization and for the convenience of the study, Coimbatore city is selected.

\subsection{Collection of Data}

Primary and secondary data was used in the present study. The study was mainly based on primary data. The primary data has been collected through a wellstructured interview schedule. From various sources such as Magazines, websites and newspaper, secondary data was collected.

\section{RESULT AND DISCUSSION}

The data collected were analyzed, categorized, tabulated and interpreted based on the objective of the study.

Table 1: Demographic Profile of the Respondents $(n=140)$

\begin{tabular}{|l|l|c|c|}
\hline Profile Factors & \multicolumn{1}{|c|}{ Particulars } & No. & Percent \\
\hline \multirow{4}{*}{ Gender } & Male & 22 & 15.71 \\
\cline { 2 - 4 } & Female & 118 & 84.28 \\
\cline { 2 - 4 } & Total & 140 & 100.00 \\
\hline \multirow{5}{*}{ Age } & Below 20 years & 0 & 0 \\
\cline { 2 - 4 } & 21-30 years & 15 & 10.71 \\
\cline { 2 - 4 } & 31-40 years & 59 & 42.14 \\
\cline { 2 - 4 } & 41-60 years & 49 & 35.00 \\
\cline { 2 - 4 } & Above 60 years & 17 & 12.14 \\
\cline { 2 - 4 } & Total & 140 & 100.00 \\
\hline
\end{tabular}




\begin{tabular}{|c|c|c|c|}
\hline \multicolumn{4}{|c|}{ Table 1: Contd., } \\
\hline \multirow{3}{*}{ Marital status } & Married & 22 & 15.71 \\
\hline & Single & 118 & 84.28 \\
\hline & Total & 140 & 100.00 \\
\hline \multirow{4}{*}{ Household size } & Less than or equal 2 members & 18 & 12.85 \\
\hline & 3-5 members & 118 & 84.28 \\
\hline & $>5$ members & 4 & 2.85 \\
\hline & Total & 140 & 100.00 \\
\hline \multirow{5}{*}{ Education } & Illiterate & 4 & 2.85 \\
\hline & School level & 37 & 26.42 \\
\hline & Undergraduate & 84 & 60.00 \\
\hline & Postgraduate & 15 & 10.71 \\
\hline & Total & 140 & 100.00 \\
\hline \multirow{7}{*}{ Occupation } & Agriculture & 0 & 0 \\
\hline & Govt. employee & 12 & 8.57 \\
\hline & Private employee & 24 & 17.14 \\
\hline & Business & 13 & 9.28 \\
\hline & Retired person & 8 & 5.71 \\
\hline & Doesn't work & 83 & 59.28 \\
\hline & Total & 140 & 100.00 \\
\hline \multirow{6}{*}{ Monthly income (Rs.) } & Below Rs. 10000 & 3 & 2.14 \\
\hline & Rs. 10001 to 20000 & 6 & 4.28 \\
\hline & Rs.20001 to 30000 & 28 & 20.00 \\
\hline & Above 30000 & 16 & 11.42 \\
\hline & Family income & 87 & 62.14 \\
\hline & Total & 140 & 100.00 \\
\hline
\end{tabular}

Source: Primary data

From the above table 1 , it is inferred that Majority ( 84.28 percent) of the sample respondents are female, 42.14 percent of the sample respondents belong to the age group of $31-40$ years, 84.28 percent of the sample respondents are married, nearly 84.28 percent of the sample respondents has household size of about $3-5$ members, 60.00 percent of the sample respondents are undergraduate, and nearly 59.28 percent of the sample respondents doesn't work andalmost 62.14 percent of the sample respondents has family income.

Table 2: Distribution of Respondents Based on Sensory Appeal. (n=140)

\begin{tabular}{|c|c|c|c|c|}
\hline Sl. No & Sensory Appeal & Particulars & $\begin{array}{c}\text { No.of } \\
\text { Respondents }\end{array}$ & $\begin{array}{c}\text { Percentage } \\
\text { Total }\end{array}$ \\
\hline \multirow{6}{*}{1} & \multirow{6}{*}{ Tastes good } & Highly satisfied & 0 & 0 \\
\hline & & Satisfied & 0 & 0 \\
\hline & & Neutral & 0 & 0 \\
\hline & & Dissatisfied & 21 & 15.00 \\
\hline & & Highly dissatisfied & 119 & 85.00 \\
\hline & & Total & 140 & 100.00 \\
\hline \multirow{6}{*}{2} & \multirow{6}{*}{ Smells nice } & Highly satisfied & 0 & 0 \\
\hline & & Satisfied & 0 & 0 \\
\hline & & Neutral & 0 & 0 \\
\hline & & Dissatisfied & 10 & 7.14 \\
\hline & & Highly dissatisfied & 130 & 92.85 \\
\hline & & Total & 140 & 100.00 \\
\hline
\end{tabular}


From the above table 2 , it is inferred that majority ( 85.00 percent) of the sample respondents are highly dissatisfied because of the taste of green tea and almost 15.00 percent of the sample respondents are also dissatisfied because of the taste of green tea. Then 92.85 percent of the sample respondents are highly dissatisfied because of the odourless nature of green tea and also 7.14 percent of the sample respondents are dissatisfied because of the odourless nature of green tea.

Table 3: Distribution of Respondents Based on Health. $(n=140)$

\begin{tabular}{|c|c|c|c|c|}
\hline SI.No & Health & Particulars & $\begin{array}{c}\text { No. of } \\
\text { Respondents }\end{array}$ & $\begin{array}{c}\text { Percentage } \\
\text { Total }\end{array}$ \\
\hline \multirow{6}{*}{1} & \multirow{6}{*}{$\begin{array}{l}\text { Contains lot of antioxidants, } \\
\text { vitamins and minerals }\end{array}$} & Highly satisfied & 131 & 93.57 \\
\hline & & Satisfied & 9 & 6.42 \\
\hline & & Neutral & 0 & 0 \\
\hline & & Dissatisfied & 0 & 0 \\
\hline & & Highly dissatisfied & 0 & 0 \\
\hline & & Total & 140 & 100.00 \\
\hline \multirow{6}{*}{2} & \multirow{6}{*}{ Keeps me healthy } & Highly satisfied & 135 & 96.42 \\
\hline & & Satisfied & 5 & 3.57 \\
\hline & & Neutral & 0 & 0 \\
\hline & & Dissatisfied & 0 & 0 \\
\hline & & Highly dissatisfied & 0 & 0 \\
\hline & & Total & 140 & 100.00 \\
\hline \multirow{6}{*}{3} & \multirow{6}{*}{ Is helps to lower cholesterol level } & Highly satisfied & 106 & 75.71 \\
\hline & & Satisfied & 34 & 24.28 \\
\hline & & Neutral & 0 & 0 \\
\hline & & Dissatisfied & 0 & 0 \\
\hline & & Highly dissatisfied & 0 & 0 \\
\hline & & Total & 140 & 100.00 \\
\hline
\end{tabular}

From the above table 3, it is concluded that majority (93.57) percent of the sample respondents are highly satisfied as green tea contains antioxidants, vitamins and minerals and 6.42 percent of the sample respondents are satisfied by the presence of antioxidants, minerals and vitamins in green tea. Also, 96.42 percent of the sample respondents are highly satisfied by drinking green tea as it improves their health and 3.57 percent of the sample respondents are also satisfied by drinking green tea. Majority (75.71 percent) of the sample respondents are highly satisfied by drinking green tea as it helps to lower cholesterol level and also 24.28 percent of the sample respondents are satisfied by drinking green tea.

Table 4: Distribution of Respondents Based on Traditional Value $\quad(n=140)$

\begin{tabular}{|c|l|l|c|c|}
\hline Sl.No & Traditional Value & \multicolumn{1}{|c|}{ Particulars } & No.of Respondents & Percentage Total \\
\hline \multirow{4}{*}{1} & \multirow{4}{*}{$\begin{array}{l}\text { Is familiar with me } \\
\text { and my family }\end{array}$} & Highly satisfied & 99 & 70.71 \\
\cline { 3 - 5 } & Satisfied & Neutral & 14 & 19.28 \\
\cline { 3 - 5 } & & Dissatisfied & 0 & 10.00 \\
\cline { 3 - 5 } & & Highly dissatisfied & 0 & 0 \\
\cline { 3 - 5 } & & Total & $\mathbf{1 4 0}$ & $\mathbf{1 0 0 . 0 0}$ \\
\hline
\end{tabular}


From the above table 4, it is concluded that majority (70.71 percent) of the sample respondents are highly satisfied as green tea is familiar with their family and nearly 19.28 percent of the sample respondents are satisfied as green tea is familiar with their family.

Table 5: Distribution of Respondents Based on Quality and Safety. (n=140)

\begin{tabular}{|c|c|c|c|c|}
\hline Sl.no & Quality and Safety & Particulars & $\begin{array}{c}\text { No.of } \\
\text { Respondents }\end{array}$ & $\begin{array}{c}\text { Percentage } \\
\text { Total }\end{array}$ \\
\hline \multirow{6}{*}{1} & \multirow{6}{*}{ Has eco-friendly packaging } & Highly satisfied & 35 & 25.00 \\
\hline & & Satisfied & 70 & 50.00 \\
\hline & & Neutral & 35 & 25.00 \\
\hline & & Dissatisfied & 0 & 0 \\
\hline & & Highly dissatisfied & 0 & 0 \\
\hline & & Total & 140 & $\mathbf{1 0 0 . 0 0}$ \\
\hline \multirow{6}{*}{2} & \multirow{6}{*}{ Has a clear origin of production } & Highly satisfied & 135 & 96.42 \\
\hline & & Satisfied & 5 & 3.57 \\
\hline & & Neutral & 0 & 0 \\
\hline & & Dissatisfied & 0 & 0 \\
\hline & & Highly dissatisfied & 0 & 0 \\
\hline & & Total & 140 & 100.00 \\
\hline
\end{tabular}

From the above 5 table, it is inferred that 50.00 percent of the sample respondents are satisfied by the ecofriendly packaging of the green tea and nearly 25.00 percent of the sample respondents are highly satisfied and also 25.00 percent of the sample respondents are neutral by the ecofriendly packaging of green tea.Almost 96.42 percent of the sample respondents are highly satisfied with the origin of the production of green tea.

Table 6: Distribution of Respondents Based on Price. (n=140)

\begin{tabular}{|c|c|c|c|c|}
\hline Sl.no & Price & Particulars & No.of Respondents & Percentage Total \\
\hline \multirow{6}{*}{1} & \multirow{6}{*}{ Is not expensive } & Highly satisfied & 0 & 0 \\
\hline & & Satisfied & 0 & 0 \\
\hline & & Neutral & 0 & 0 \\
\hline & & Dissatisfied & 56 & 40.00 \\
\hline & & Highly dissatisfied & 84 & 60.00 \\
\hline & & Total & 140 & 100.00 \\
\hline \multirow{6}{*}{2} & \multirow{6}{*}{ Is cheap } & Highly satisfied & 0 & 0 \\
\hline & & Satisfied & 0 & 0 \\
\hline & & Neutral & 0 & 0 \\
\hline & & Dissatisfied & 56 & 40.00 \\
\hline & & Highly dissatisfied & 84 & 60.00 \\
\hline & & Total & 140 & 100.00 \\
\hline \multirow{6}{*}{3} & \multirow{6}{*}{$\begin{array}{l}\text { Is good value of } \\
\text { money }\end{array}$} & Highly satisfied & 8 & 5.71 \\
\hline & & Satisfied & 132 & 94.28 \\
\hline & & Neutral & 0 & 0 \\
\hline & & Dissatisfied & 0 & 0 \\
\hline & & Highly dissatisfied & 0 & 0 \\
\hline & & Total & 140 & 100.00 \\
\hline
\end{tabular}

From the above table 6 , it is concluded that majority (60.00 percent) of the sample respondents are highly dissatisfied by the expensive price of green tea and 40.00 percent of the sample respondents are dissatisfied by the expensive price of green tea. Nearly 60.00 percent of the sample respondents are highly satisfied and 40.00 percent of the sample respondents are dissatisfied by the cost of green tea. Almost 94.28 percent of the sample respondents are satisfied 
as purchasing green tea is a good value of money and nearly 5.71 percent of the sample respondents also feel it is a good value of money.

Table 7: Distribution of Respondents Based on Convenience ( $n=140)$

\begin{tabular}{|c|c|c|c|c|}
\hline Sl.no & Convenience & Particulars & No.of Respondents & Percentage Total \\
\hline \multirow{6}{*}{1} & \multirow{6}{*}{ Is easy to prepare } & Highly satisfied & 140 & 100.00 \\
\hline & & Satisfied & 0 & 0 \\
\hline & & Neutral & 0 & 0 \\
\hline & & Dissatisfied & 0 & 0 \\
\hline & & Highly dissatisfied & 0 & 0 \\
\hline & & Total & 140 & 100.00 \\
\hline \multirow{6}{*}{2} & \multirow{6}{*}{ Takes no time to prepare } & Highly satisfied & 140 & 100.00 \\
\hline & & Satisfied & 0 & 0 \\
\hline & & Neutral & 0 & 0 \\
\hline & & Dissatisfied & 0 & 0 \\
\hline & & Highly dissatisfied & 0 & 0 \\
\hline & & Total & 140 & 100.00 \\
\hline \multirow[t]{6}{*}{3} & \multirow{6}{*}{$\begin{array}{l}\text { Can be bought in shops close to } \\
\text { where I live or work }\end{array}$} & Highly satisfied & 59 & 42.14 \\
\hline & & Satisfied & 39 & 27.85 \\
\hline & & Neutral & 42 & 30.00 \\
\hline & & Dissatisfied & 0 & 0 \\
\hline & & Highly dissatisfied & 0 & 0 \\
\hline & & Total & 140 & 100.00 \\
\hline \multirow{6}{*}{4} & \multirow{6}{*}{$\begin{array}{l}\text { Is easily available in shops and } \\
\text { supermarkets }\end{array}$} & Highly satisfied & 140 & 100.00 \\
\hline & & Satisfied & 0 & 0 \\
\hline & & Neutral & 0 & 0 \\
\hline & & Dissatisfied & 0 & 0 \\
\hline & & Highly dissatisfied & 0 & 0 \\
\hline & & Total & 140 & 100.00 \\
\hline
\end{tabular}

From the above table 7,it is inferred that almost 100.00 percent of the sample respondents are highly satisfied as green tea is easy to prepare. Also, 100.00 percent of the sample respondents are highly satisfied as it takes no time to prepare and 42.14 percent of the sample respondents are highly satisfied as that green tea can be bought easily at nearby shops and also 27.85 percent of the sample respondents are satisfied and 30.00 percent of the sample respondents are neutral as green tea can be bought at nearby shops. Mostly 100.00 percent of the sample respondents are highly satisfied as green tea is easily available in shops and supermarkets.

Table 8: Constraints Faced by the Consumers at the Time of Purchase (n=140)

\begin{tabular}{|c|l|c|c|}
\hline Sl.no & \multicolumn{1}{|c|}{ Constraints } & Garett's Score & Rank \\
\hline 1 & Price & 68.929 & I \\
\hline 2 & Package & 50 & II \\
\hline 3 & Lack of availability of brands & 35.53 & III \\
\hline 4 & Lack of availability of flavours & 34.286 & IV \\
\hline 5 & Lack of awareness & 32.143 & V \\
\hline
\end{tabular}

From the above table 8 , it can be inferred that price is considered as an important constraint by the green tea consumers because the price of green tea is high. The second constraint is package (50) in which there is no different means of packaging in green tea and the third constraint in which lack of availability of brands (35.53). In the retail stores 
of Coimbatore, there are not much brands of green tea.The fourth constraint is lack of availability of flavours (34.28) and the fifth constraint is lack of awareness (32.14) about green tea in Coimbatore city.

\section{CONCLUSIONS}

The present study was carried out with 140 respondents in which they are purposively selected from Coimbatore city. The well-structured self-prepared interview schedule was prepared to collect the relevant information from the respondents. Results showed that majority ( 85 percent) of the sample respondents is highly dissatisfied because of the taste of green tea, and then 92.85 percent of the sample respondents are highly dissatisfied because of the odourless nature of green tea. Majority (93.57) percent of the sample respondents are highly satisfied as green tea contains antioxidants, vitamins and minerals.Also, 96.42 percent of the sample respondents are highly satisfied by drinking green tea as it improves their health. Majority (75.71 percent) of the sample respondents are highly satisfied by drinking green tea as it helps to lower cholesterol level, majority (70.71 percent) of the sample respondents are highly satisfied as green tea is familiar with their family, 50.00 percent of the sample respondents are satisfied by the ecofriendly packaging of the green tea and nearly 25.00 percent of the sample respondents are highly satisfied with the ecofriendly packaging of green tea. Almost 96.42 percent of the sample respondents are highly satisfied with the origin of production of green tea, majority (60.00 percent) of the sample respondents are highly dissatisfied by the expensive price of green tea and 60.00 percent of the sample respondents are highly satisfied and 40.00 percent of the sample respondents are dissatisfied by the cost of green tea.

Almost 100.00 percent of the sample respondents are highly satisfied as green tea is easy to prepare. Also, 100.00 percent of the sample respondents are highly satisfied as it takes no time to prepare and 42.14 percent of the sample respondents are highly satisfied as that green tea can be bought easily at nearby shops. Mostly 100.00 percent of the sample respondents are highly satisfied as green tea is easily available in shops and supermarkets. Almost 94.28 percent of the sample respondents are satisfied as purchasing green tea is a good value of money and price is considered as an important constraint by the green tea consumers because the price of green tea is high.

Tea is considered as the most popular drink next to coffee. Green tea has been consumed all over the world by millions of people because of its health benefits. Green tea helps to lower blood sugar level, lowers the incidence of stroke, and lowers cholesterol and also decrease in total lipids. Hence, consumers are highly satisfied by drinking green tea.

\section{REFERENCES}

1. Font-i-Furnols, M., \& Guerrero, L. (2014). Consumer preference, behavior and perception about meat and meat products: An overview. Meat science, 98(3), 361-371.

2. Nazanin Soudbakhsh Moghadam, Anil Kumar H.V \& Muralidhar. S. Talkad, "Therapeutic Potential of Methanolic Extract of Evolvulus Alsinoides Plant for Anti Cancer Activities in Vitro“, International Journal of Applied and Natural Sciences (IJANS), Vol. 6,issue 3,pp. 1-8

3. Guleria, D., \& Parmar, Y. S. (2015). A study of consumer preference for smartphone: A case of Solan town of Himachal Pradesh. International journal of management research \& review, 5(3), 1-20.

4. Kim Dang, A., Xuan Tran, B., Tat Nguyen, C., Thi Le, H., Thi Do, H., Duc Nguyen, H., ... \& Ngo, C. (2018). Consumer preference and attitude regarding online food products in Hanoi, Vietnam. International journal of environmental research and public health, 15(5), 981 
5. Mohini Mendiratta \& Sarika Gupta, "Exploration of the Role of Phytochemicals and Antioxidants for Antihyperglycemic Potentials of Indian Medicinal Plants “, International Journal of General Medicine and Pharmacy (IJGMP), Vol. 6, Issue 4,pp. $21-32$

6. Kanav Jain \& Padmanidhi Agarwal , "Green Tea as a Treatment Modality for Dentinal Erosion “, International Journal of Dental Research \& Development (IJDRD), Vol. 8, Issue 1, pp. 9-14

7. Parimala, C. (2017). A study on consumer response towards electronic product with special reference in Pudukkottai town.International Research Journal of Management Sociology \& Humanity, Page 250

8. O’Donovan, P., \& McCarthy, M. (2002). Irish consumer preference for organic meat. British Food Journal.

9. Bhatia, M., \& Jain, A. (2013). Green marketing: A study of consumer perception and preferences in India. Electronic Green Journal, 1(36).

10. Ravish Kumar Chauhan, "Role of Chemistry in Everyday Life ", BEST: International Journal of Humanities, Arts, Medicine and Sciences (BEST: IJHAMS), Vol. 3, Issue 11, pp. 67-74

11. Prabhavathi, Y., Kishore, N. K., \& Kumar, M. R. (2014). Consumer preference and spending pattern in Indian fast food industry. International journal of scientific and research publications, 4(2), 5. 